\title{
ECHOCARDIOGRAPHIC EVALUATION OF THE RIGHT HEART
}

\author{
ROSHANAK R MARKLEY, MD ${ }^{1}$, ASGHAR ALI, MD ${ }^{1,2}$, JONATHAN POTFAY, MD ${ }^{1,2}$, \\ WALTER PAULSEN, MD ${ }^{1}$, AND ION S JOVIN, MD ${ }^{1,2}$ \\ ${ }^{1}$ DEPARTMENT OF MEDICINE, VIRGINIA COMMONWEALTH UNIVERSITY, RICHMOND, VA, USA \\ ${ }^{2}$ DEPARTMENT OF MEDICINE, MCGUIRE VA MEDICAL CENTER, RICHMOND, VA, USA
}

The appropriate use of echocardiography may reduce the need for invasive diagnostic cardiac procedures. The right side of the heart has recently gained interest among cardiologists as it became clear that abnormalities of the right heart morphology and function are associated with increased morbidity and mortality. Echocardiography is easy to perform, relatively cheap, readily available and do not pose the risk of ionizing radiation. Conventional 2D and, more recently, 3D echocardiography provides pertinent anatomic and physiologic information about the right side of the heart. Because of the advantages and simplicity of echocardiography it continues to be an excellent tool for evaluating the structure and function of the right side of the heart. This review outlines the uses of echocardiography in evaluating the right heart structure and function.

KEY WORDS: Right heart · Right ventricle · Echocardiography.

\section{INTRODUCTION}

The right ventricle (RV) is anterior to the left ventricle (LV) and behind the sternum which has implications for its specific morbidity and mortality but which also makes it potentially accessible to surface imaging such as transthoracic echocardiography. Assessment of right heart function remains relatively difficult despite technological advancement in echocardiography because of the unusual crescent shape, the irregular endocardial surface, complex contraction mechanism and location of the RV. ${ }^{12)}$ However, the introduction of Doppler and color Doppler techniques as well as improvements in image quality and imaging modalities has made it possible to use echocardiography as a modality to assess the structure and function of the right heart. ${ }^{3-5)}$ Jaussi et al. ${ }^{6}$ concluded that it is prudent to evaluate the right heart structures in detail as the prevalence of right heart abnormalities found on routine echocardiography is significant.

\section{NORMAL STRUCTURE AND FUNCTION}

The RV is immediately behind the sternum and is the most anterior part of the heart which is bordered by the annulus of the tricuspid and pulmonary valve. It is crescent shaped in cross sectional view and triangle shaped in the side view (Fig. 1).
Anatomically, the RV consists of inflow tract, the apex and infundibulum. ${ }^{5) 8)}$ There are three prominent bands present in the RV of which the moderator band distinguishes RV from $\mathrm{LV}^{5}{ }^{59)}$ The ventriculoinfundibular fold is another important structure that separates the tricuspid and pulmonary valves, which is in contrast to the LV where the aortic and mitral valves are in fibrous continuity. When assessing the RV volume the complex shape and infundibulum should be included. ${ }^{10)}$ The shape can also be influenced by the septum which is concave toward the LV in both systole and diastole. The normal RV measurements by 2D echocardiography are; base apex length less than $8.6 \mathrm{~cm}$, midcavity diameter less than $3.5 \mathrm{~cm}$, basal diameter less than $4.2 \mathrm{~cm}$, RV outlet parasternal short axis $2.7 \mathrm{~cm}$, RV outlet parasternal long axis $3.3 \mathrm{~cm}$, and end diastolic area less than $28 \mathrm{~cm}^{2}$. ${ }^{14)}$

There are different modalities to assess RV function (Table 1). The RV ejection fraction is driven by right ventricular preload, after load and contractility. ${ }^{11)}$ The tricuspid annular plane systolic excursion is correlated to RV ejection fraction ${ }^{12)}$ which has a mean value of $52.3 \pm 6.2 \%$ with $40 \%$ being the lower limit of normal and there is about $5 \%$ increase during exercise $^{13)}$ and is used as a surrogate for global RV systolic function. $\mathrm{RV}$ dimensions and function can be measured by standard M-

\footnotetext{
- Received: July 20, $2015 \cdot$ Revised: May 3, 2016 •Accepted: July 26, 2016

- Address for Correspondence: Asghar Ali, Department of Medicine, McGuire VA Medical Center, 1201 Broad Rock Boulevard, Richmond, VA 23249, USA

Tel: +1-804-675-6439, Fax: +1-804-675-5601, E-mail: mirasgharali@yahoo.com

- This is an Open Access article distributed under the terms of the Creative Commons Attribution Non-Commercial License (http://creativecommons.org/licenses/by-nc/3.0)

which permits unrestricted non-commercial use, distribution, and reproduction in any medium, provided the original work is properly cited.
} 


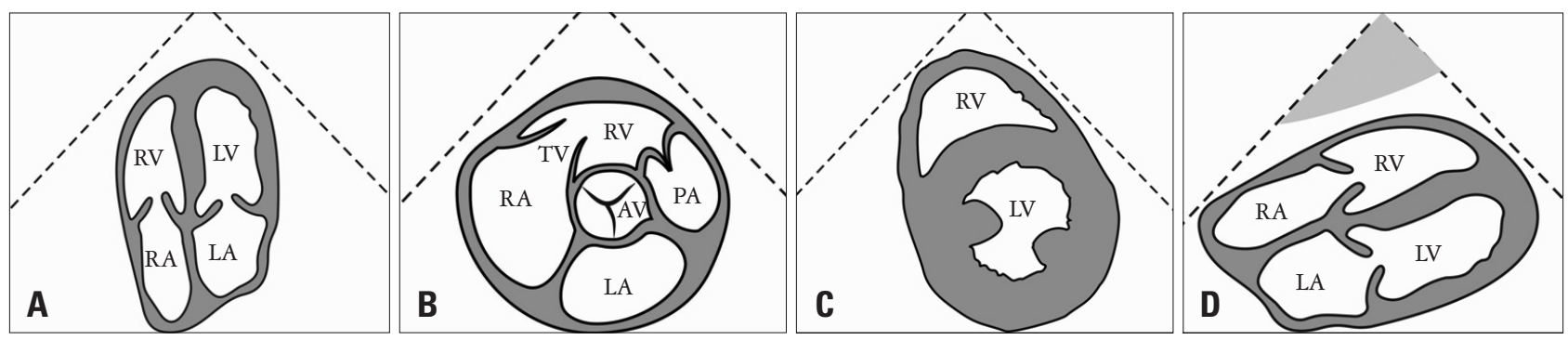

Fig. 1. Echocardiographic views most frequently used to assess the structure and function of the right heart. Apical four chamber view (A). Parasternal short axis view at the level of the aortic valve showing the right atrium (RA), right ventricle (RV), right ventricular outflow tract, pulmonary valve and main pulmonary artery (B). Parasternal short axis view at the level of the papillary muscles (C). Subcostal four chamber view (D). AV: aortic valve, LA: left atrium, LV: left ventricle, PA: pulmonary artery, TV: tricuspid valve.

Table 1. Studies evaluating right ventricular function

\begin{tabular}{|c|c|c|c|}
\hline Author, year & Study subjects & Comparison with gold standard & Correlation \\
\hline Iriart et al., $2012^{51)}$ & 35 & $\begin{array}{l}\text { 2D echocardiography vs. MRI to assess } \\
\text { RV function }\end{array}$ & $\begin{array}{l}\text { Interobserver and intraobserver echocardiographic analysis } \\
\text { variability was high }(>10 \%) \text { for RV EF, RV FS and dP/dt, } \\
\text { and low }(5 \%) \text { for TAPSE and TDI }\end{array}$ \\
\hline Lu et al., 2008 25$)$ & 20 & $\begin{array}{l}\text { 3D echocardiography vs. MRI to assess } \\
\text { RV function }\end{array}$ & $\begin{array}{l}\text { Intraobserver and interobserver variability ranged from }-1.1 \% \\
\text { to } 5.8 \%\end{array}$ \\
\hline Jenkins et al., $2007^{23)}$ & 50 & $\begin{array}{l}\text { 2D echocardiography vs. 3D } \\
\text { echocardiography vs. MRI to assess } \\
\text { RV function }\end{array}$ & $\begin{array}{l}\text { Interobserver variability for EDV and EF by } 2 \mathrm{D} \\
\text { echocardiography and } 3 \mathrm{D} \text { echocardiography was comparable } \\
\text { (EDV: } p=0.93, \mathrm{z}=0.10 \text { vs. } p=0.72, \mathrm{z}=0.37 \text {; } \\
\text { EF: } p=0.23, \mathrm{z}=1.26 \text { vs. } p=0.27, \mathrm{z}=1.14) \text {, but for ESV } \\
\text { 3D echocardiography was better }(p=0.01, \mathrm{z}=2.72 \text { vs. } \\
p=0.01, \mathrm{z}=3.24)\end{array}$ \\
\hline Nesser et al., $2006^{10)}$ & 20 & $\begin{array}{l}\text { Transthoracic 3D echocardiography vs. } \\
\text { transesophageal echocardiography vs. } \\
\text { MRI vs. radionuclide ventriculography } \\
\text { to assess RV function }\end{array}$ & $\begin{array}{l}\text { RV EF by radionuclide ventriculography and MRI correlated } \\
\text { well with EF by transesophageal echocardiography }(\mathrm{r}=0.95 \text {, } \\
\text { mean difference } 0.2 \%) \text { and by transthoracic 3D } \\
\text { echocardiography }(\mathrm{r}=0.95 \text {, mean difference } 1.8 \%)\end{array}$ \\
\hline$\underset{2002^{29)}}{\text { Raymond et al., }}$ & 81 & $\begin{array}{l}\text { 2D echocardiography vs. right sided } \\
\text { cardiac catheterization, and } 6 \text { min walk } \\
\text { test in patients with right heart failure }\end{array}$ & $\begin{array}{l}\text { Pericardial effusion }(p=0.017) \text {, right atrial index }(p=0.012) \text {, } \\
\text { and diastolic eccentricity index }(p=0.004) \text { are predictors } \\
\text { of death or transplantation }\end{array}$ \\
\hline $\begin{array}{l}\text { Papavassiliou et al., } \\
1998^{22)}\end{array}$ & 13 & $\begin{array}{l}\text { 3D echocardiography vs. MRI to asses } \\
\text { RV function }\end{array}$ & $\begin{array}{l}\text { 3D echocardiography correlation was modest for EF } \\
\left(\mathrm{R}^{2}=0.64\right)\end{array}$ \\
\hline Tei et al., $1996^{31)}$ & 63 & $\begin{array}{l}\text { 2D echocardiography vs. right sided } \\
\text { cardiac catheterization to asses } \mathrm{RV} \\
\text { function }\end{array}$ & $\begin{array}{l}\text { Echocardiography showed minimal interobserver and } \\
\text { intraobserver differences }(3.3 \% \text { and } 4.5 \% \text {, respectively) } \\
\text { for systolic and diastolic right ventricular dysfunction }\end{array}$ \\
\hline Kaul et al., $1984^{12)}$ & 30 & $\begin{array}{l}\text { 2D echocardiography vs. radionuclide } \\
\text { ventriculography to assess RV function }\end{array}$ & $\begin{array}{l}\text { Correlation of TAPSE and RV end-diastolic area with RV EF } \\
\text { is close }(r=0.92 \text { and } r=-0.76 \text {, respectively) }\end{array}$ \\
\hline
\end{tabular}

mode, 2D echocardiography and Doppler echocardiography, the findings correlate with ejection fraction derived by radionuclide angiography. ${ }^{14)}$ Another method for measuring the RV function is myocardial performance index or the Tei index. It is calculated as the ratio between total RV isovolumic time (contraction and relaxation) divided by pulmonary ejection time. The RV myocardial performance index has been shown to correlate with pulmonary pressures and can be used to identify RV dysfunction. ${ }^{15-17)}$ The normal RV systolic functional values by echocardiography; tricuspid annular plane excursion greater than $16 \mathrm{~mm}$, fractional area change greater than 35\%, and peak systolic tissue Doppler velocity at tricuspid annulus greater than $10 \mathrm{~cm}$ per second. The diastolic RV function values by echocardiography; tricuspid E/A ratio less than 0.8 is consistent with decreased relaxation, tricuspid E/A ratio 0.8 to 2.1 with $\mathrm{E} / \mathrm{E}$ ' ratio greater than 6 is consistent with falsely normal filling, and tricuspid $\mathrm{E} / \mathrm{A}$ ratio greater than 2.1 with deceleration lime less than $120 \mathrm{msec}$ is consistent with restrictive filling. ${ }^{14)}$

Doppler tissue imaging is set to detect low velocity with high amplitude, which provides accurate information on myocardial motion throughout the cardiac cycle, detects myocardial tissue motion as opposed to red cells and is used to derive strain and strain rate, both of which are less preload dependent as compared to traditional ejection fraction. ${ }^{18-21)} 3 \mathrm{D}$ echocardiography may have a potential advantage in determining RV volumes and image reconstruction; however this technique re- 
mains limited because of poor lateral resolution in right ventricular cavity dilatation. ${ }^{22)}$ Due to limited studies it is recommended that 3D echocardiography can be utilized only for serial volume and ejection fraction evaluation with the RV ejection fraction lower limit set at $44 \%$ as this modality has lesser underestimation than 2D echocardiography when compared to cardiac magnetic resonance imaging. ${ }^{2324)}$ In recent years real time 3D echocardiography has been found to be a valuable tool for assessing the RV anatomy and function. 3D echocardiography is reproducible, easily available, and accurate despite the geometric challenges placed by the RV structure and position. $^{25) 26)}$

The right atrium not only acts as a conduit to fill the RV passively but also optimizes RV filling actively during late diastole. Anatomical deformities of the spine and chest can alter the right atrium and project larger dimensions. Echocardiographic four chamber apical views are used to evaluate the right atrium and the subcostal views to evaluate the inferior vena cava.

\section{CHANGES IN FUNCTION}

$\mathrm{RV}$ systolic function is a reflection of contractility, afterload, and preload. RV performance is also influenced by heart rhythm, synchrony of ventricular contraction, RV force interval relationship, and ventricular interdependence. ${ }^{27}$

$\mathrm{RV}$ pressure overload can be due to obstruction of the RV outflow tract (pulmonary stenosis), primary pulmonary hypertension or secondary pulmonary hypertension. In the absence of RV outflow tract obstruction, the tricuspid regurgitation jet can be used to assess the pulmonary artery systolic pressure. ${ }^{28)}$ Endsystolic flattening of the interventricular septum is an indication of RV pressure overload. With chronic increase in afterload the RV dilates and hypertrophies, the tricuspid annulus might also dilate and cause severe tricuspid regurgitation. Right atrial area index, diastolic eccentricity index and pericardial effusion score are indicators of morbidity and potential mortality. ${ }^{29)} \mathrm{RV}$ hypertrophy is defined as the RV free wall thickness greater than 5-7 $\mathrm{mm}$ measured at the end-diastole by $\mathrm{M}$-mode or $2 \mathrm{D}$ echocardiography from either parasternal
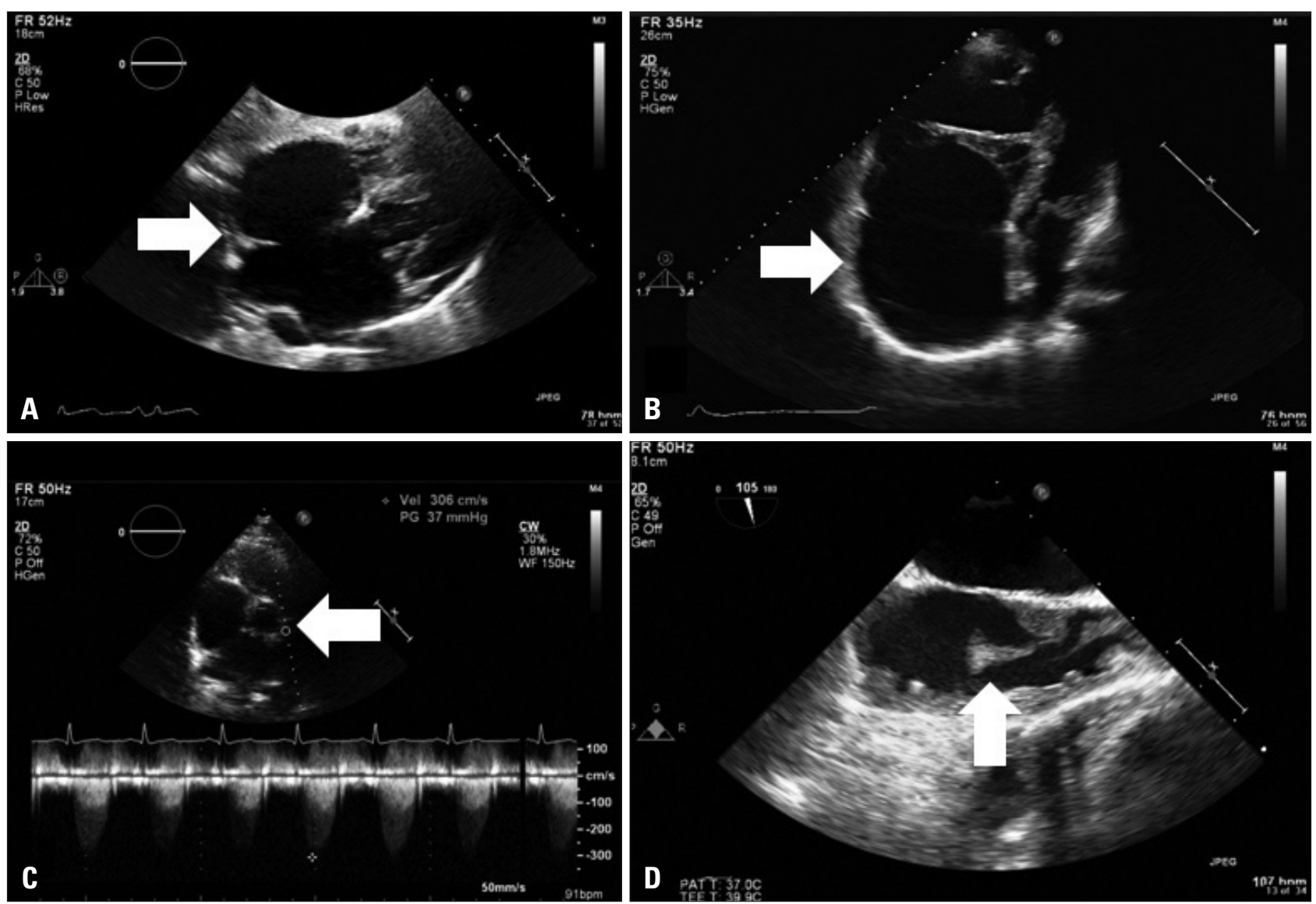

Fig. 2. Echocardiographic images of right heart abnormalities. Atrial septal defect in a 53-year-old woman with transient ischemic attack who declined closure (A, transesophageal echocardiography, 0 degree, arrow pointing at interatrial septum); Ebstein's anomaly in a 41-year-old man with severe tricuspid regurgitation, right atrial enlargement ( $B$, apical four chamber view, arrow showing severely enlarged right atrium), right ventricular dysfunction and right heart failure who subsequently underwent tricuspid valve repair, right atrial reduction and maze procedure; pulmonary valve stenosis in a 38-year-old woman who had congenital pulmonic valve stenosis subsequently corrected by balloon valvuloplasty; Doppler showing high velocities across the valve ( $\mathrm{C}$, transesophageal echocardiography, 0 degree, arrow pointing at pulmonary valve plane); and right atrial thrombus (measuring $2 \mathrm{~cm}$ in length) in a 30-year-old woman who had systemic lupus erythematosus and end stage renal disease with just removed status of central venous catheter ( $D$, transesophageal echocardiography, 105 degree, arrow pointing at the end of the pedunculated thrombus). 
long axis or subcostal window.

$\mathrm{RV}$ volume overload can be result of left to right shunting as in atrial septal defect (Fig. 2A), pulmonary anomalous venous return or ventricular septal defect. ${ }^{30)}$ Significant valvular regurgitation can also contribute to RV volume overload. Color Doppler studies, venous injection of microbubbles as well as image acquisition in the subcostal view or transesophageal echocardiography are often useful tools in echocardiography to assess RV structure and function in a volume overload state. When the right ventricular volume is high the $\mathrm{LV}$ acquires a $\mathrm{D}$ shape in diastole as result of the interventricular interdependence which can be visualized by echocardiography. ${ }^{133}$

$\mathrm{RV}$ diastolic dysfunction is an independent predictor of mortality $^{31)}$ with a complex pathophysiology which can be evaluated by the trans-tricuspid $\mathrm{E} / \mathrm{A}$ ratio, the $\mathrm{E} / \mathrm{E}$ ' ratio, and the right atrial size. ${ }^{1)}$

Right atrial echocardiographic measurements take longer time that most other measurements, but are valuable in assessing RV and $\mathrm{LV}$ dysfunction. ${ }^{14)}$ Lower global longitudinal strain of $\mathrm{RV}(\geq-15.5 \%)$ in patients with pulmonary arterial hypertension measured with velocity vector imaging using $2 \mathrm{D}$ strain echocardiographic measurement was found to have increased mortality. ${ }^{32)} 3 \mathrm{D}$ and 2D echocardiographic apical four chamber planimetry area is utilized for evaluating right atrial volume. ${ }^{33)}$ In patients with primary pulmonary hypertension right atrial area is a predictor of transplantation or mortality. Patients on mechanical ventilators pose challenges in evaluating the right atrium in the setting of inferior vena caval collapse. The normal right atrial measurements by $2 \mathrm{D}$ echocardiography are; minor dimension less than $4.4 \mathrm{~cm}$, major dimension less than $5.3 \mathrm{~cm}$, and end systolic area less than $20 \mathrm{~cm}^{2}$. ${ }^{14)}$

\section{CHANGES IN STRUCTURE}

The structural changes in the right heart can be due to congenital anomalies, valvular disease, myocardial disease or postoperative changes (Fig. 2A).

\section{CONGENITAL RIGHT HEART DISEASE}

The echocardiography is useful in diagnosing and following congenital heart disease because it is easy to perform, readily available, relatively inexpensive, although magnetic resonance imaging is used more and more for these patients. ${ }^{34)}$ Appropriate use of echocardiography may also decrease the need for invasive diagnostic procedures. ${ }^{35)}$ In congenital heart disease, the $\mathrm{RV}$ may support the pulmonary or systemic circulation and can lead to RV dysfunction over time which is known to be associated with increased morbidity and mortality and therefore will need close monitoring and surveillance. The combination of 2D echocardiography and Doppler can provide extensive information on the anatomy and function of the heart. ${ }^{3036)}$

The important congenital anomalies affecting the right ventricular inflow tract and tricuspid valve can be diagnosed by specific findings on echocardiography. Tricuspid atresia is a condi- tion in which the lack of development of the RV leads to low pulmonary flow in addition to the imperforate valvular membrane between the floor of the right atrium and the hypoplastic RV. 2D echocardiography shows an echo-dense band of fibrofatty tissue of the atrioventricular groove and the absent right atrioventricular connection. ${ }^{37)}$ In patients with Ebstein's anomaly (Fig. 2B), the echocardiography will reveal an apical displacement of the septal leaflet of the tricuspid valve, tethering of the tricuspid valve causing restricted motion of the leaflet, marked enlargement of the right atrium (with an atrialized $\mathrm{RV}$ ), and tricuspid regurgitation. ${ }^{27)}$ The underdevelopment of the right ventricular myocardium, or as Uhl's disease, leads to right ventricular dilatation and eventually right ventricular failure.

The right ventricular outflow tract and the corresponding anomalies can be visualized by echocardiography in a similar fashion. Subvalvular stenosis usually involving the infundibulum results from fibromuscular narrowing or hypertrophied subvalvular muscle bundles also called double-chambered $\mathrm{RV}^{38)}$ Double-chambered RV is difficult to visualize with echocardiography and subcostal echocardiography may provide optimal visualization. ${ }^{3940)}$ Typically subvalvular stenosis is a dynamic form of obstruction with maximal flow velocity occurring in late systole. Valvular pulmonary stenosis may lead to ventricular hypertrophy and subsequent outflow tract narrowing. In this form of obstruction, using 2D echocardiography, the pulmonary cusps appear thickened, have a decreased excursion and dome in systole with a resulting increased peak instantaneous pressure gradient (Fig. 2C); however, this technique is limited for assessing the severity of obstruction. ${ }^{4142)}$ Furthermore, the pulmonary arteries should always be assessed in children with right ventricular outflow tract obstruction because the development of the pulmonary arteries can be affected by the flow and pulmonary artery stenosis can be associated with other congenital cardiac and extracardiac lesions. ${ }^{43)}$ Color Doppler imaging can be used to assess the turbulence and acceleration of flow within the stenotic segment.

Arrhythmogenic right ventricular dysplasia, a congenital autosomal dominant myocardial disease that is characterized by progressive fibrofatty replacement of the myocardium, can lead to ventricular tachycardia and sudden death in young people and especially in athletes. Diagnosis of arrhythmogenic right ventricular dysplasia can be made by variety of invasive and non-invasive modalities but magnetic resonance imaging is considered the gold standard. 2D echocardiographic findings suggestive of arrhythmogenic right ventricular dysplasia are RV dilatation, altered myocardial texture, localized RV aneurysms and inferobasal or localized dyskinesia. ${ }^{44(5)} 3 \mathrm{D}$ echocardiography is a useful modality; however, currently interpretations are variable based on the centers and guidelines have not been established.

Tetralogy of Fallot is the most common cyanotic congenital heart disease. This anomaly has four anatomical features: 1 ) 
anterior and rightward displacement of the aortic root, 2) ventricular septal defect, 3) right ventricular outflow obstruction, and 4) right ventricular hypertrophy. ${ }^{46) 47)}$ Echocardiography can be used for de novo diagnosis of the lesion, in determining options for surgical intervention and postoperative assessment of the adequacy of repair. In tetralogy of Fallot, the most critical defect is the mal-alignment of the infundibular septum, resulting in septal defect and overriding aorta. This is optimally visualized in the parasternal long-axis view. The short axisview allows for determining the extent and size of the septal defect in addition to assessment of the right ventricular outflow tract. ${ }^{46-48)}$ Color Doppler is useful in assessing the location of the narrowed, turbulent flow, and continuous wave Doppler can then be used to determine the pressure gradient across the obstruction. Additionally coronary artery anatomy must be examined before surgery. In addition to coronary angiography, this can also be done by using 2D echocardiography techniques such as visualizing a coronary artery branch across the right ventricular outflow tract. ${ }^{46-48)}$ Postoperatively the ventricular septal defect patch can be seen in the parasternal long-axis view as the linear structure passing obliquely from septum to anterior aortic root, shunting can be evaluated using Doppler, and right ventricular size and contractility should be assessed. The $\mathrm{RV}$ volume is better evaluated by $3 \mathrm{D}$ echocardiography in post tetralogy of Fallot surgery. ${ }^{49)}$

Transposition of the great arteries is another common congenital heart disease which refers to the aorta arising from the $\mathrm{RV}$ and the pulmonary artery arising from the LV. The parasternal long-axis view demonstrates normal ventricular relationship with ventriculoarterial discordance. The diagnosis of Dtransposition is confirmed in the subcostal four chamber view where a bifurcating great artery is seen arising from the LV as the pulmonary artery. ${ }^{36) 50-52)}$ The current standard for correction of this anatomic anomaly is an arterial switch where both great arteries are transected and re-anastomosed to the correct ventricle. Tissue Doppler echocardiography with strain and strain rate imaging is a good modality to evaluate myocardial function in patients who have undergone correction of transposition of great arteries. ${ }^{36)}$ Postoperative echocardiographic evaluation should focus on assessment of the left and right ventricular function, valvular narrowings, anastomotic site, and the origin of the coronaries. ${ }^{53)}$

Double-outlet RV refers to congenital heart disease with an anomalous bundle of muscle which divides the right heart into a high pressure inlet and a low pressure outlet, both great arteries arise from the RV and ventricular septal defect acts as the only outlet for the LV. Echocardiographic diagnosis is based on demonstration of the muscular bundle and both great arteries arising to the right of the ventricular septum which is best visualized in the parasternal-axis and subcostal coronal views. This view will also help determine the lack of fibrous continuity between the posterior semilunar valve and the anterior mitral valve leaflet. ${ }^{40) 54)}$ Echocardiographic assessment after repair should focus on ventricular septal defect patch, presence of outflow obstruction and possibility of semilunar valve regurgitation. ${ }^{55)}$

\section{ACQUIRED RIGHT HEART DISEASE}

Valvular diseases that are acquired are also easily diagnosed and characterized by 2D echocardiography and Doppler or by transesophageal echocardiography. These include carcinoid heart disease, tricuspid rheumatic stenosis, pulmonary and tricuspid valve endocarditis, pulmonary and tricuspid valve insufficiency, or post-valvuloplasty pulmonary insufficiency. ${ }^{56-58)}$

The majority of symptoms of restrictive cardiomyopathies are due to left ventricular involvement; however, restrictive cardiomyopathies are often a global process and can affect the RV in varying degrees of hypertrophy, infiltration and abnormalities of tricuspid inflow which can be easily detected on $2 \mathrm{D}$ echocardiography by detecting changes in myocardial texture and on Doppler by detecting changes in flow. ${ }^{59)(6)} \mathrm{RV}$ infarct can also be detected by echocardiography by evaluating the RV regional wall motion, its size, volume and global function. ${ }^{61)}$

Transthoracic echocardiography plays a role in corroborating the diagnosis of suspected pulmonary embolism and help guide management. ${ }^{62)}$ The echocardiographic indices that are measured to evaluate for pulmonary embolism included RV/ $\mathrm{LV}$ area ratio, $\mathrm{RV} / \mathrm{LV}$ end diastolic dimension ratio, the McConnell sign, interventricular septal shift (D sign), pulmonary artery diameter, tricuspid regurgitation velocity, and the "60/60" sign. Of all the indices measured, RV/LV end diastolic dimension ratio $>0.7$ had good accuracy for diagnosis of acute pulmonary embolism. This ratio, in addition to McConnell sign, were specific but not sensitive. ${ }^{63)}$ In fact, presence of RV dysfunction, and hemodynamic instability in massive pulmonary embolism and cardiogenic shock is an indication for emergency removal of pulmonary thrombus using thrombolytics or embolectomy or catheter-based thrombus aspiration. ${ }^{64)}$

\section{RIGHT HEART MASSES}

\section{THROMBI}

Thromboembolism and infections are a major complication associated with long term central venous catheters, port devices or pacer/implantable cardioverter defibrillator (ICD) leads. Rarely pacer/ICD leads can also migrate and cause perforations. In a retrospective study done by Chow et al., ${ }^{65)} 185$ patients who received ICD's between 1991 and 1999 were assessed by transesophageal echocardiography at $120 \pm 213$ days after implantation. Forty six $(25 \%)$ were diagnosed with ICD lead-related thrombi on follow-up echocardiography. Patients treated with oral anticoagulation were less likely to have thrombus formation. There was a higher incidence of lead-related thrombus in polyurethane leads than in silicone leads (35\% vs. $20 \% ; p=0.01)$.

Right heart thrombi can also form in patients with inherited 
or acquired thrombophilia. These thrombi can be mobile or free floating or fixed. The mobile thrombi, probably originating in the peripheral veins, significantly increase the risk for pulmonary embolism. The fixed thrombi usually develop in the right heart and have a more benign prognosis. These thrombi can be detected with high sensitivity (Fig. 2D) by transesophageal echocardigraphy. ${ }^{60}$

\section{TUMORS}

Right heart tumors can be non-primary or primary tumors of the heart. Non-primary tumors are more frequent and most likely the result of direct spread from adjacent malignancies or metastases from primary sites such as lung or breast cancer, lymphoma or melanoma. Primary tumors of the heart can be benign or malignant; however the benign primary tumors outnumber the malignant ones by a ratio of 3 to $1 .^{67(68)}$ Benign tumors of the right heart can be lipomas, myxomas, fibroelastomas or leiomyoma. Echocardiography can be helpful in distinguishing between different types of tumors based on their appearances and locations. Myxomas are often found in the left atrium. They are irregularly shaped with filamentous fronds and typically non-homogeneous. ${ }^{68-70)}$ On the other hand, papillary fibroelastomas appear speckled with echolucencies near the edges. ${ }^{69)}$ Lipomas are uncommon and may affect the atrial septum where fatty infiltration of the septum results in dramatic thickening and increased echogenicity which gives it a "dumbbell-shaped" appearance on echocardiography. ${ }^{677}$ Rhabdomyosarcomas are rare tumors. ${ }^{71)}$ They appear as distinct, highly echogenic, and well-demarcated masses that often extend into the cavity of the ventricle. ${ }^{67)}$ Malignant tumors of the right heart occur with less frequency and include angiosarcomas which are the commonest primary malignant tumor and rhabdomyosarcomas. ${ }^{6772)}$ Malignant tumors tend to invade or replace the myocardial tissue and alter the appearance on echocardiography. The heart often appears tethered and immobile. These tumors can be easily detected with 2D echocardiography; however, because they are less common than metastatic tumors, such echo findings should suggest the possibility of metastatic disease. $^{73)}$

\section{EXTRINSIC CHANGES AFFECTING THE RIGHT HEART}

Pericardial effusions can be trivial and can be seen along the right atrial border on subcostal view. However, effusions can cause hemodynamic compromise by compressing the right heart structures. In fact, isolated right atrial or both right atrial and ventricular diastolic collapse and altered inflow patterns by Doppler are sensitive signs for tamponade physiology. ${ }^{\text {74) }}$ Thoracic masses can also cause distortion or partial displacement or encroachment of the right heart structures as well as some degree of cavity obliteration or compression and cause tamponade physiology. In this case, the preferred method of evaluation is transesophageal echocardiography. ${ }^{75)}$

\section{SUMMARY}

Over the past several years there has been renewed awareness about right heart and the fact that an impaired right heart function may be associated with an increased morbidity and mortality. The advantage of echocardiography over other modalities is that it is readily available, is easy to perform, is inexpensive and does not subject the patient to ionizing radiation. It is a great tool to evaluate the right heart structure and function. M-mode, 2D echocardiography with conventional Doppler and tissue Doppler as well as 3D echocardiography and it can provide significant insight into right heart physiology and pathology. As we continue to appreciate the importance of the right heart it becomes prudent to utilize echocardiography as a routine diagnostic modality to evaluate the right side of the heart in outpatient, emergency room, and inpatient settings.

- Acknowledgements

The authors thank Mary Beatty Brooks for her great help with the illustrations.

\section{REFERENCES}

1. Rudski LG, Lai WW, Afilalo J, Hua L, Handschumacher MD, Chandrasekaran K, Solomon SD, Louie EK, Schiller NB. Guidelines for the echocardiographic assessment of the right heart in adults: a report from the American Society of Echocardiography endorsed by the European Association of Echocardiography, a registered branch of the European Society of Cardiology, and the Canadian Society of Echocardiography. J Am Soc Echocardiogr 2010;23:685-713; quiz 786-8.

2. Napp LC, Luesebrink U, Vogel-Claussen J, Bauersachs J, Roentgen P. Two's company: double-chambered right ventricle (corrected). Circulation 2013;127:e469-70.

3. Jurcut R, Giusca S, La Gerche A, Vasile S, Ginghina C, Voigt JU. The echocardiographic assessment of the right ventricle: what to do in 2010? Eur J Echocardiogr 2010;11:81-96.

4. Valsangiacomo Buechel ER, Mertens LL. Imaging the right heart: the use of integrated multimodality imaging. Eur Heart J 2012;33:949-60.

5. Horton KD, Meece RW, Hill JC. Assessment of the right ventricle by echocardiography: a primer for cardiac sonographers. J Am Soc Echocardiogr 2009;22:776-92; quiz 861-2.

6. Jaussi A, Crittin J, Bloch A. (Echocardiography of the right heart--unknown territory. Contribution of echocardiography and Doppler echocardiography to the study of the right heart). Schweiz Rundsch Med Prax 1989;78: 494-7.

7. Foale R, Nihoyannopoulos P, McKenna W, Kleinebenne A, Nadaz$\operatorname{din}$ A, Rowland E, Smith G. Echocardiographic measurement of the normal adult right ventricle. Br Heart J 1986;56:33-44.

8. Ho SY, Nihoyannopoulos P. Anatomy, echocardiography, and normal right ventricular dimensions. Heart 2006;92 Suppl 1:i2-13.

9. Farb A, Burke AP, Virmani R. Anatomy and pathology of the right ventricle (including acquired tricuspid and pulmonic valve disease). Cardiol Clin 1992;10:1-21.

10. Nesser HJ, Tkalec W, Patel AR, Masani ND, Niel J, Markt B, Pandian NG. Quantitation of right ventricular volumes and ejection fraction by three-dimensional echocardiography in patients: comparison with magnetic resonance imaging and radionuclide ventriculography. Echocardiography 2006;23:666-80.

11. Bleasdale RA, Frenneaux MP. Prognostic importance of right ventricular dysfunction. Heart 2002;88:323-4.

12. Kaul S, Tei C, Hopkins JM, Shah PM. Assessment of right ventricular 
Right Heart Echocardiography | Roshanak R Markley, et al.

function using two-dimensional echocardiography. Am Heart J 1984;107: 526-31.

13. Pfisterer ME, Battler A, Zaret BL. Range of normal values for left and right ventricular ejection fraction at rest and during exercise assessed by radionuclide angiocardiography. Eur Heart J 1985;6:647-55.

14. Ghio S, Gavazzi A, Campana C, Inserra C, Klersy C, Sebastiani R, Arbustini E, Recusani F, Tavazzi L. Independent and additive prognostic value of right ventricular systolic function and pulmonary artery pressure in patients with chronic heart failure. J Am Coll Cardiol 2001;37:183-8.

15. Vonk MC, Sander MH, van den Hoogen FH, van Riel PL, Verheugt FW, van Dijk AP. Right ventricle Tei-index: a tool to increase the accuracy of non-invasive detection of pulmonary arterial bypertension in connective tissue diseases. Eur J Echocardiogr 2007;8:317-21.

16. Eidem BW, O'Leary PW, Tei C, Seward JB. Usefulness of the myocardial performance index for assessing right ventricular function in congenital heart disease. Am J Cardiol 2000;86:654-8.

17. Eidem BW, Tei C, O'Leary PW, Cetta F, Seward JB. Nongeometric quantitative assessment of right and left ventricular function: myocardial performance index in normal children and patients with Ebstein anomaly. $J$ Am Soc Echocardiogr 1998;11:849-56.

18. Hatle L, Sutherland GR. Regional myocardial function--a new approach. Eur Heart J 2000;21:1337-57.

19. Isaaz K, Munoz del Romeral L, Lee E, Schiller NB. Quantitation of the motion of the cardiac base in normal subjects by Doppler echocardiography. $J$ Am Soc Echocardiogr 1993;6:166-76.

20. Yalçin F, Kaftan A, Muderrisoğlu H, Korkmaz ME, Flachskampf F, Garcia M, Thomas JD. Is Doppler tissue velocity during early left ventricular filling preload independent? Heart 2002;87:336-9.

21. Gondi S, Dokainish H. Right ventricular tissue Doppler and strain imaging: ready for clinical use? Echocardiography 2007;24:522-32.

22. Papavassiliou DP, Parks WJ, Hopkins KL, Fyfe DA. Three-dimensional echocardiographic measurement of right ventricular volume in children with congenital heart disease validated by magnetic resonance imaging. J Am Soc Echocardiogr 1998;11:770-7.

23. Jenkins C, Chan J, Bricknell K, Strudwick M, Marwick TH. Reproducibility of right ventricular volumes and ejection fraction using real-time three-dimensional echocardiography: comparison with cardiac MRI. Chest 2007;131:1844-51.

24. Gopal AS, Chukwu EO, Iwuchukwu CJ, Katz AS, Toole RS, Schapiro W, Reichek N. Normal values of right ventricular size and function by real-time 3-dimensional echocardiography: comparison with cardiac magnetic resonance imaging. J Am Soc Echocardiogr 2007;20:445-55.

25. Lu X, Nadvoretskiy V, Bu L, Stolpen A, Ayres N, Pignatelli RH, Kovalchin JP, Grenier M, Klas B, Ge S. Accuracy and reproducibility of real-time three-dimensional echocardiography for assessment of right ventricular volumes and ejection fraction in children. J Am Soc Echocardiogr 2008; 21:84-9.

26. Wang XF, Deng YB, Nanda NC, Deng J, Miller AP, Xie MX. Live three-dimensional echocardiography: imaging principles and clinical application. Echocardiography 2003;20:593-604.

27. Haddad F, Hunt SA, Rosenthal DN, Murphy DJ. Right ventricular function in cardiovascular disease, part I: anatomy, physiology, aging, and functional assessment of the right ventricle. Circulation 2008;117:1436-48.

28. Lindqvist P, Calcutteea A, Henein M. Echocardiography in the assessment of right heart function. Eur J Echocardiogr 2008;9:225-34.

29. Raymond RJ, Hinderliter AL, Willis PW, Ralph D, Caldwell EJ, Williams W, Ettinger NA, Hill NS, Summer WR, de Boisblanc B, Schwartz T, Koch G, Clayton LM, Jöbsis MM, Crow JW, Long W. Echocardiographic predictors of adverse outcomes in primary pulmonary bypertension. J Am Coll Cardiol 2002;39:1214-9.

30. Davlouros PA, Niwa K, Webb G, Gatzoulis MA. The right ventricle in congenital heart disease. Heart 2006;92 Suppl 1:i27-38.
31. Tei C, Dujardin KS, Hodge DO, Bailey KR, McGoon MD, Tajik AJ, Seward SB. Doppler echocardiographic index for assessment of global right ventricular function. J Am Soc Echocardiogr 1996;9:838-47.

32. Park JH, Park MM, Farha S, Sharp J, Lundgrin E, Comhair S, Tang WH, Erzurum SC, Thomas JD. Impaired global right ventricular longitudinal strain predicts long-term adverse outcomes in patients with pulmonary arterial hypertension. J Cardiovasc Ultrasound 2015;23:91-9.

33. Müller H, Burri H, Lerch R. Evaluation of right atrial size in patients with atrial arrhythmias: comparison of $2 D$ versus real time $3 D$ echocardiography. Echocardiography 2008;25:617-23.

34. Kilner PJ. Imaging congenital heart disease in adults. Br J Radiol 2011;84 Spec No 3:S258-68.

35. Koestenberger M. Transthoracic echocardiography in children and young adults with congenital heart disease. ISRN Pediatr 2012;2012:753481.

36. Rentzsch A, Abd El Rahman MY, Hui W, Helweg A, Ewert P, Gutberlet M, Lange PE, Berger F, Abdul-Khaliq H. Assessment of myocardial function of the systemic right ventricle in patients with D-transposition of the great arteries after atrial switch operation by tissue Doppler echocardiography. Z Kardiol 2005;94:524-31.

37. Orie JD, Anderson C, Ettedgui JA, Zuberbuhler JR, Anderson RH. Echocardiographic-morphologic correlations in tricuspid atresia. J Am Coll Cardiol 1995;26:750-8.

38. Alva C, Ho SY, Lincoln CR, Rigby ML, Wright A, Anderson RH. The nature of the obstructive muscular bundles in double-chambered right ventricle. J Thorac Cardiovasc Surg 1999;117:1180-9.

39. Lascano ME, Schaad MS, Moodie DS, Murphy D Jr. Difficulty in diagnosing double-chambered right ventricle in adults. Am J Cardiol 2001;88: 816-9.

40. McElhinney DB, Chatterjee KM, Reddy VM. Double-chambered right ventricle presenting in adulthood. Ann Thorac Surg 2000;70:124-7.

41. Geibel A. (Echocardiographic evaluation in unoperated congenital heart disease in adultss. Herz 1999;24:276-92.

42. Fitzgerald KP, Lim MJ. The pulmonary valve. Cardiol Clin 2011;29: 223-7.

43. Hernandez RJ, Bank ER, Shaffer EM, Snider AR, Rosenthal A. Comparative evaluation of the pulmonary arteries in patients with right ventricular outflow tract obstructive lesions. AJR Am J Roentgenol 1987;148: 1189-94.

44. Yoerger DM, Marcus F, Sherrill D, Calkins H, Towbin JA, Zareba W, Picard MH; Multidisciplinary Study of Right Ventricular Dysplasia Investigators. Echocardiographic findings in patients meeting task force criteria for arrhythmogenic right ventricular dysplasia: new insights from the multidisciplinary study of right ventricular dysplasia. J Am Coll Cardiol 2005;45:860-5.

45. Kjærgaard J. Assessment of right ventricular systolic function by tissue Doppler echocardiography. Dan Med J 2012;59:B4409.

46. Apitz C, Webb GD, Redington AN. Tetralogy of Fallot. Lancet 2009; 374:1462-71.

47. Shinebourne EA, Babu-Narayan SV, Carvalho JS. Tetralogy of Fallot: from fetus to adult. Heart 2006;92:1353-9.

48. Bleeker GB, Steendijk P, Holman ER, Yu CM, Breithardt OA, Kaandorp TA, Schalij MJ, van der Wall EE, Nihoyannopoulos P, Bax JJ. Assessing right ventricular function: the role of echocardiography and complementary technologies. Heart 2006;92 Suppl 1:i19-26.

49. Dragulescu A, Grosse-Wortmann L, Fackoury C, Mertens L. Echocardiographic assessment of right ventricular volumes: a comparison of different techniques in children after surgical repair of tetralogy of Fallot. Eur Heart J Cardiovasc Imaging 2012;13:596-604.

50. Warnes CA. Transposition of the great arteries. Circulation 2006;114: 2699-709.

51. Iriart X, Horovitz A, van Geldorp IE, Barnetche T, Lederlin M, De Guillebon M, Réant P, Lafitte S, Thambo JB. The role of echocardiogra- 
phy in the assessment of right ventricular systolic function in patients with transposition of the great arteries and atrial redirection. Arch Cardiovasc Dis 2012;105:432-41.

52. George L, Waldman JD, Mathewson JW, Kirkpatrick SE, Pappelbaum SJ, Turner SW. Two-dimensional echocardiographic discrimination of normal from abnormal great artery relationships. Clin Cardiol 1983;6: 327-32.

53. Martin RP, Qureshi SA, Ettedgui JA, Baker EJ, O’Brien BJ, Deverall PB, Yates AK, Maisey MN, Radley-Smith R, Tynan M. An evaluation of right and left ventricular function after anatomical correction and intraatrial repair operations for complete transposition of the great arteries. Circulation 1990;82:808-16.

54. Hoffman P, Wójcik AW, Rózański J, Siudalska H, Jakubowska E, Włodarska EK, Kowalski M. The role of echocardiography in diagnosing double chambered right ventricle in adults. Heart 2004;90:789-93.

55. Choi YJ, Park SW. Characteristics of double-chambered right ventricle in adult patients. Korean J Intern Med 2010;25:147-53.

56. Reményi B, Wilson N, Steer A, Ferreira B, Kado J, Kumar K, Lawrenson J, Maguire G, Marijon E, Mirabel M, Mocumbi AO, Mota C, Paar J, Saxena A, Scheel J, Stirling J, Viali S, Balekundri VI, Wheaton G, Zühlke L, Carapetis J. World Heart Federation criteria for echocardiographic diagnosis of rheumatic heart disease--an evidence-based guideline. Nat Rev Cardiol 2012;9:297-309.

57. Pellikka PA, Tajik AJ, Khandheria BK, Seward JB, Callahan JA, Pitot HC, Kvols LK. Carcinoid heart disease. Clinical and echocardiographic spectrum in 74 patients. Circulation 1993;87:1188-96.

58. San Román JA, Vilacosta I, López J, Revilla A, Arnold R, Sevilla T, Rollán MJ. Role of transthoracic and transesophageal echocardiography in right-sided endocarditis: one echocardiographic modality does not fit all. J Am Soc Echocardiogr 2012;25:807-14.

59. Berensztein CS, Piñeiro D, Marcotegui M, Brunoldi R, Blanco MV, Lerman J. Usefulness of echocardiography and doppler echocardiography in endomyocardial fibrosis. J Am Soc Echocardiogr 2000;13:385-92.

60. Nihoyannopoulos P, Dawson D. Restrictive cardiomyopathies. Eur J Echocardiogr 2009;10:iii23-33.

61. Esmaeilzadeh M, Parsaee M, Maleki M. The role of echocardiography in coronary artery disease and acute myocardial infarction. J Tehran Heart Cent 2013;8:1-13.
62. Lodato JA, Ward RP, Lang RM. Echocardiographic predictors of pulmonary embolism in patients referred for helical CT. Echocardiography 2008; 25:584-90.

63. Leibowitz D. Role of echocardiography in the diagnosis and treatment of acute pulmonary thromboembolism. J Am Soc Echocardiogr 2001;14:921-6.

64. Konstantinides S. (Diagnosis and therapy of pulmonary embolism). Vasa 2006;35:135-46.

65. Chow BJ, Hassan AH, Chan KL, Tang AS. Prevalence and significance of lead-related thrombi in patients with implantable cardioverter defibrillators. Am J Cardiol 2003;91:88-90.

66. Eweda II, Samir S, Abbas O, El-Gohary GM, Nammas W. Right heart thrombus-in-transit with pulmonary embolism in a patient with primary bypercoagulable state. Cardiol J 2010;17:408-11.

67. Meng Q, Lai H, Lima J, Tong W, Qian Y, Lai S. Echocardiographic and pathologic characteristics of primary cardiac tumors: a study of 149 cases. Int J Cardiol 2002;84:69-75.

68. Gopal AS, Stathopoulos JA, Arora N, Banerjee S, Messineo F. Differential diagnosis of intracavitary tumors obstructing the right ventricular outflow tract.J Am Soc Echocardiogr 2001;14:937-40.

69. Klarich KW, Enriquez-Sarano M, Gura GM, Edwards WD, Tajik AJ, Seward JB. Papillary fibroelastoma: echocardiographic characteristics for diagnosis and pathologic correlation. J Am Coll Cardiol 1997;30:78490.

70. Lacey BW, Lin A. Radiologic evaluation of right ventricular outflow tract myxomas. Tex Heart Inst J 2013;40:68-70.

71. Sokullu O, Sanioglu S, Deniz H, Ayoglu U, Ozgen A, Bilgen F. Primary cardiac rhabdomyosarcoma of the right atrium: case report. Heart Surg Forum 2008;11:E117-9.

72. Amonkar GP, Deshpande JR. Cardiac angiosarcoma. Cardiovasc Pathol 2006; 15:57-8.

73. Labib SB, Schick EC Jr, Isner JM. Obstruction of right ventricular outflow tract caused by intracavitary metastatic disease: analysis of 14 cases. $\mathrm{J} \mathrm{Am}$ Coll Cardiol 1992;19:1664-8.

74. Bodson L, Bouferrache K, Vieillard-Baron A. Cardiac tamponade. Curr Opin Crit Care 2011;17:416-24.

75. D'Cruz IA, Feghali N, Gross CM. Echocardiographic manifestations of mediastinal masses compressing or encroaching on the heart. Echocardiography 1994;11:523-33. 